\title{
Proton Affinities of Polyglycines Assessed By Using the Kinetic Method
}

\author{
Zhuchun $\mathrm{Wu}$ and Catherine Fenselau \\ Department of Chemistry and Biochemistry, University of Maryland Baltimore County, \\ Baltimore, Maryland, USA
}

The proton affinities of a series of peptides, chosen to show the effects of chain length, were measured by the kinetic method using amines as standard reference bases. Proton affinities of polyglycines with residues ranging from 2 to 10 were measured and the values were found to increase as the number of residues increases. (J Am Soc Mass Spcctram 1992, 3, $863-866$ )

W ith the development of ionization methods such as fast-atom bombardment (FAB) and electrospray, studies of the ion-molecule chemistry of nonvolatile materials in the gas phase have experienced rapid growth, especially for peptides and proteins $[1,2]$. Basicities and acidities analogous to acid-base properties in solution are important chemical properties of molecules and ions in the gas phase. In the gas phase these properties are intrinsic, in contrast to those in the solution where solvation has a large effect. At the same time, gas-phase basicity can be used to explain many mass spectrometry phenom ena. For example, it is well known that the existence and position of basic residues in peptides will greatly influence the collision-activated dissociation spectra of peptides [1], and recently detailed and quantitative studies of mechanisms of fragmentation of peptides relative to their basicities have appeared in the literature $[3,4]$. In the electrospray ionization technique, ion formation is also believed to depend on proton bonding energy and desolvation energy [5]. All these stimulate our study of proton affinities of peptides.

Proton affinities of all 20 common amino acids have been measured using several quite different methods [6-11]. It is not surprising to find some differences between these measurements. However, general trends are consistent: $\mathrm{Gly}, \mathrm{Ala}$, and Cys are less basic amino acids, and Lys, His, and Arg are more basic amino acids. Recently we measured the proton affinity of arginine by the kinetic method as $245.2 \pm 0.5 \mathrm{kcal} / \mathrm{mol}$ [12]. This value is about $14 \mathrm{kcal} / \mathrm{mol}$ higher than that of histidine, the nearest most basic amino acid, in

\footnotetext{
Address reprint requests to Catherine Fenselau, Department of Chemistry and Biochemistry. University of Maryland Baltimore County, 5401 Wilkens Road, Baltimore, MD 21228.
}

contrast to the average difference of $1 \mathrm{kcal} / \mathrm{mol} \mathrm{be-}$ tween the other nineteen amino acids. Here we report our study on the proton affinities of a series of peptides designed to test the effects of chain length by using the kinetic method.

The kinetic method [13] has been widely used to measure not only proton affinities [14, 15] but also gas-phase acidities [16, 17] and electron affinities [18]. It is applicable to nonvolatile and small amounts of samples and easily employed in commercial tandem instruments. It offers the possibility of discriminating between proton affinities that differ by less than 0.1 $\mathrm{kcal} / \mathrm{mol}$. Where comparison is possible, it has provided values in very good agreement with those measured by thermodynamic equilibrium approaches.

The relative gas-phase proton affinities (PA) can be determined from the rates of the following unimolecular dissociation reactions of proton-bound dimer ions [13]:

$$
\begin{aligned}
& {\left[\mathrm{B}_{1} \cdots \cdot \mathrm{H} \cdots \cdot \mathrm{B}_{2}\right]^{+} \rightarrow \mathrm{B}_{1}+\left[\mathrm{B}_{2}+\mathrm{H}\right]^{+}} \\
& {\left[\mathrm{B}_{1} \cdots \cdots \mathrm{H} \cdots \cdots \mathrm{B}_{2}\right]^{+} \rightarrow \mathrm{B}_{2}+\left[\mathrm{B}_{1}+\mathrm{H}\right]^{+}}
\end{aligned}
$$

From the absolute rate theory

$$
\ln \left(k_{1} / k_{2}\right)=\ln \left(Q_{1}^{*} / Q_{2}^{*}\right)+\Delta \mathrm{PA} / R T
$$

where $k_{1}$ and $k_{2}$ are the rate constants of the competing reactions $1 \mathrm{a}$ and $1 \mathrm{~b}$ respectively, which can be determined simply by the relative ion abundances in the mass-analyzed ion kinetic energy (MIKL) spectra. $Q_{1}^{*}$ and $Q_{2}^{*}$ are the partition functions of the activated complexes for the competing reactions $1 \mathrm{a}$ and $1 \mathrm{~b}$ respectively. If $B_{1}$ and $B_{2}$ are chemically similar species, then $Q_{1}^{*}=Q_{2}^{*}$ and eq 2 becomes $\ln \left(k_{1} / k_{2}\right)=\Delta \mathrm{PA} / R T$. 


\section{Experimental}

Experiments reported here were similar to those in the earlier work that determined the proton affinity of arginine [12]. All MIKE experiments were performed on a JEOL JMS-HX110/HX110 (JEOL USA, Peabody, MA; Palo Alto, CA) tandem mass spectrometer using EBE geometry. The proton-bound dimer ions are simply generated by a JEOL FAB gun operated at $5 \mathrm{kV}$. Proton-bound dimer ions were extracted at $10 \mathrm{kV}$, selected by the first two sectors (EB), then allowed to dissociate spontaneously in the third field-free region without the use of collision gas, and detected immediately after passage through the second electrostatic analyzer. 'The spectra were averaged profile data of four or five scans with acquisition time for every scan about $30 \mathrm{sec}$.

Polyglycines of two through six glycine units were purchased from Sigma Chemical Co. (St. Louis, MO) and amines from Aldrich Chemical Co. (Milwaukee, WI). Heptaglycine, octaglycine, and decaglycine were synthesized by the Biopolymer Laboratory in the University of Maryland at Baltimore. Typically, $1 \mathrm{mg}$ of sample was dissolved in $20 \mu \mathrm{L}$ of $1 \%$ trifluoroacetic acid (TFA) solution. To optimize the abundance of the cluster ions, extra TFA was added to some solutions. Decaglycine was dissolved in dimethyl sulfoxide.

3-Nitrobenzyl alcohol was used as FAB matrix, except that for decaglycine a mixture in the ratio $5 / 1$ of dithiothreitol and dithioerythritol was used. We found that changing the FAB matrix, the resolution of the mass spectrometer, or the FAB gun voltage did not significantly affect the ratios of product ion abundances (standard deviations were less than 5\%). This indicates that the ratio depends on only the native properties of the gas-phase proton-bound dimer ions.

\section{Results and Discussion}

In all experiments we used amines as standard reference bases to determine the proton affinities of peptides. To assess the effects of using structurally different amines as reference bases, we have selected different annines with the same proton affinilies as reference bases to measure the proton affinities of diglycine and tetraglycine. Propylamine (primary amine) and 4-chloropyridine (tertiary amine) have the same proton affinities (PA $=217.8 \mathrm{kcal} / \mathrm{mol}$ ) [19]. Assuming the temperature is $350 \mathrm{~K}$ (see below) and $Q_{1}^{*}=Q_{2}^{*}$, according to eq 2 we calculated that for diglycine these two reference bases provide proton affinities that differ by less than $\pm 0.6 \mathrm{kcal} / \mathrm{mol}$. The difference between proton affinities determined for tetraglycine is even smaller $(0.3 \mathrm{kcal} / \mathrm{mol})$, measured with either a secondary amine (dipropylamine, PA $=227.5 \mathrm{kcal} / \mathrm{mol}$ ) [19] or a tertiary amine (dimethylethylamine, PA = $227.5 \mathrm{kcal} / \mathrm{mol}$ ) [19]. Thus, use of structurally different amines (primary, secondary, or tertiary amines) as standard references appear to introduce only small differences in the determined proton affinity values in the present work.

The proton affinity of each peptide was determined by comparison with several amines. The ratio [peptide $+\mathrm{H}]^{\dagger} /[\text { amine }+\mathrm{H}]^{+}$or $k_{\text {(peptide) }} / k_{\text {(amine) }}$ is measured directly from the MIKE spectrum of the proton-bound dimer ions. A linear equation can be deducted from eq 2,

$$
\begin{aligned}
\ln \frac{k_{\text {(peptide) }}}{k_{(\text {amine }) i}}= & \ln \frac{Q_{(\text {peptide) }}^{*}}{Q_{(\text {amine }) i}^{*}} \\
& +\frac{1}{R T}\left[\text { PA }_{\text {(peptide) }}-P A_{(\text {am ine }) i}\right]
\end{aligned}
$$

A plot of $\ln \left(k_{\text {(peptide) }} / k_{\text {(amine) } i}\right)$ versus PA (amine)i provides a reference calibration line. Linear regression analysis of the plot then gives the sum of $\mathrm{PA}_{\text {(peptide) }} / R T$ and $\ln \left(Q_{1}^{*} / Q_{2}^{*}\right)$. If $Q_{1}^{*}=Q_{2}^{*}$, we get the proton affinity of peptide. That is the value list in Table 1 . In the case of $Q_{1}^{*} \neq Q_{2}^{*}$, the absolute values will not be reliable. If all the activated complexes of polyglycines and amines are similar, then $\ln \left(Q_{\text {(peptide) }}^{*} / Q_{(\text {amine }) i}^{*}\right)=$ $\ln \left(Q_{\text {(peptide)2 }}^{*} / Q_{(\text {amine)i }}^{*}\right)$. Therefore the relative values and hence the conclusions based on these values are reliable. Figure 1 shows the calibration line for tetraglycine. A correlation cofficient of 0.999 was obtained in this case. Considering the standard deviations of the ion abundance ratios, which are less than $5 \%$, and the error from the linear regression, we obtain an uncertainty of less than $\pm 0.1 \mathrm{kcal} / \mathrm{mol}$. But considering the uncertainties of proton affinities of reference bases in the literature, which ustually are \pm 0.3 $\mathrm{kcal} / \mathrm{mol}$, the uncertainties should be slightly higher than reported here. Therefore, we report the proton affinity of tetraglycine to be $227.2 \pm 0.1 \mathrm{kcal} / \mathrm{mol}$. All other proton affinities of peptides were determined in the same manner. The correlation coefficients range from 0.999 to 0.94 and the uncertainties range from 0.4 to $0.8 \mathrm{kcal} / \mathrm{mol}$ for diglycine to hexaglycine. For heptaglycine, octaglycine, and decaglycine, only two references bases were used. The proton affinities were estimated on the basis of eq 2, and the uncertainties are much higher for these cases.

Equation 3 also allows calculation of the effective temperature of ion pairs undergoing unimolecular dissociation [13]. The effective temperature depends, inter alia, on metastable ion internal energies, that is, the nature of metastable ions. It was interesting to find that effective temperatures are about $350 \mathrm{~K}$ for diglycine, tetraglycine, and hexaglycine, and about 600 $\mathrm{K}$ for triglycine and pentaglycine.

Peptides consist of multiple functional groups with the potential for intramolecular hydrogen bonding. Studies of the peptidelike glycine derivative $\mathrm{CH}_{3} \mathrm{CO}$ Gly- $\mathrm{OCH}_{3}(\mathrm{PA}=217.7 \mathrm{kcal} / \mathrm{mol})$ and the alanine derivative $\mathrm{CH}_{3} \mathrm{CO}-\mathrm{Ala}-\mathrm{OCH}_{3}(\mathrm{PA}=224.5 \mathrm{kcal} / \mathrm{mol})$ show that their proton affinities are about 6 and 10 $\mathrm{kcal} / \mathrm{mol}$ higher than glycine $(\mathrm{PA}=211.6 \mathrm{kcal} / \mathrm{mol}$ ) and alanine $(\mathbf{P A}=214.8 \mathrm{kcal} / \mathrm{mol})$, respectively [20]. 
Table 1. Proton affinities of polyglycines

\begin{tabular}{|c|c|c|c|c|}
\hline Polyglycine & Reference base & Ratio [G] $]_{n}$ /Base & $\mathbf{P A}^{\mathrm{a}, \mathrm{b}}$ & $\Delta P A^{c}$ \\
\hline \multirow[t]{2}{*}{ Glycine } & & & 211.6 & \\
\hline & & & & 7.5 \\
\hline \multirow[t]{5}{*}{ Diglycine } & & & $219.1 \pm 0.8$ & \\
\hline & $\mathrm{CH}_{3} \mathrm{CH}_{2} \mathrm{NH}_{2}$ & $39.2 / 1$ & 217.0 & \\
\hline & $\mathrm{CH}_{3} \mathrm{CH}_{2} \mathrm{CH}_{2} \mathrm{NH}_{2}$ & $3.99 / 1$ & $\begin{array}{l}217.9 \\
218.4\end{array}$ & \\
\hline & $\begin{array}{l}\mathrm{CH}_{3} \mathrm{CH}_{2} \mathrm{CH}_{2} \mathrm{CH}_{2} \mathrm{NH}_{2} \\
\left(\mathrm{CH}_{3}\right)_{2} \mathrm{NH}\end{array}$ & $1 / 4.976$ & $\begin{array}{l}218.4 \\
220.6\end{array}$ & \\
\hline & & & & 4.0 \\
\hline \multirow[t]{6}{*}{ Triglycine } & & & $223.1 \pm 0.5$ & \\
\hline & Cyclohexylamine & $3.87 / 1$ & 221.2 & \\
\hline & $t$-Amylamine & $2.24 / 1$ & 222.3 & \\
\hline & Dimeththylanilline & $1 / 1.63$ & 223.4 & \\
\hline & $\left\{\mathrm{CH}_{3}\right\}_{3} \mathrm{~N}$ & $1 / 5.28$ & 225.1 & \\
\hline & & & & 4.1 \\
\hline \multirow[t]{6}{*}{ Tetraglycine } & & & $227.2 \pm 0.4$ & \\
\hline & $\left(\mathrm{CH}_{3}\right)_{3} \mathrm{~N}$ & $20.8 / 1$ & 225.1 & \\
\hline & $\left(\mathrm{CH}_{3} \mathrm{CH}_{2}\right)_{2} \mathrm{NH}$ & $7.22 / 1$ & 225.9 & \\
\hline & $\left(\mathrm{CH}_{3} \mathrm{CH}_{2} \mathrm{CH}_{2}\right)_{2} \mathrm{NH}$ & $1 / 1.35$ & 227.5 & \\
\hline & $\left(\mathrm{CH}_{3} \mathrm{CH}_{2} \mathrm{CH}_{2} \mathrm{CH}_{2}\right)_{2} \mathrm{NH}$ & $1 / 6.0$ & 228.4 & \\
\hline & & & & 4.6 \\
\hline \multirow[t]{7}{*}{ Pentaglycine } & $231.8 \pm 0.7$ & & & \\
\hline & $\left(\mathrm{CH}_{3} \mathrm{CH}_{2} \mathrm{CH}_{2} \mathrm{CH}_{2}\right)_{2} \mathrm{NH}$ & $8.90 / 1$ & 228.4 & \\
\hline & $\left(\mathrm{CH}_{3}\right)\left(\mathrm{CH}_{3} \mathrm{CH}_{2}\right)_{2} \mathrm{~N}$ & $6.00 / 1$ & 230.0 & \\
\hline & (sec-Bu $)_{2} \mathrm{NH}$ & $1.24 / 1$ & 231.8 & \\
\hline & $\left(\mathrm{CH}_{3} \mathrm{CH}_{2}\right)_{3} \mathrm{~N}$ & $1.12 / 1$ & 232.3 & \\
\hline & $\left(\mathrm{CH}_{3} \mathrm{CH}_{2} \mathrm{CH}_{2}\right)_{3} \mathrm{~N}$ & $1 / 15.2$ & 234.0 & \\
\hline & & & & 2.6 \\
\hline \multirow[t]{5}{*}{ Hexaglycine } & & & $234.4 \pm 0.6$ & \\
\hline & $\left(\mathrm{CH}_{3} \mathrm{CH}_{2}\right)_{3} \mathrm{~N}$ & $29.9 / 1$ & 232.3 & \\
\hline & $\left(\mathrm{CH}_{3} \mathrm{CH}_{2} \mathrm{CH}_{2}\right)_{3} \mathrm{~N}$ & $2.87 / 1$ & 234.0 & \\
\hline & $\left(\mathrm{CH}_{3} \mathrm{CH}_{2} \mathrm{CH}_{2} \mathrm{CH}_{2}\right)_{3} \mathrm{~N}$ & $1 / 1.375$ & 234.8 & \\
\hline & & & & 2.6 \\
\hline \multirow[t]{4}{*}{ Heptaglycine } & & & $237.0 \pm 2.5$ & \\
\hline & $\left(\mathrm{CH}_{3} \mathrm{CH}_{2} \mathrm{CH}_{2} \mathrm{CH}_{2}\right)_{3} \mathrm{~N}$ & $5.49 / 1$ & 234.8 & \\
\hline & TMG & $1 / 10.9$ & $242.8^{i}$ & \\
\hline & & & & 2.5 \\
\hline \multirow[t]{4}{*}{ Octaglycine } & & & $239.5+2.5$ & \\
\hline & $\left(\mathrm{CH}_{3} \mathrm{CH}_{2} \mathrm{CH}_{2} \mathrm{CH}_{2}\right)_{3} \mathrm{~N}$ & $38.9 / 1$ & 234.8 & \\
\hline & TMG & $1 / 3.09$ & 242.8 & \\
\hline & & & & 4.5 \\
\hline \multirow[t]{3}{*}{ Decaglycine } & & & $244.0 \pm 2.5$ & \\
\hline & TMG & $3.79 / 1$ & 242.8 & \\
\hline & DBN & $1 / 1.53$ & $245.7^{d}$ & \\
\hline
\end{tabular}

a PAs in $\mathrm{kcal} / \mathrm{mol}$ of glycine and reference bases are taken from refs 19 and 21

bucertainties are estimated from standard deviations of ion abundance ratios, of the linear regressions, and of reference base values

$\triangle P A=P A\left([G]_{n}\right) \cdot P A\left([G]_{n-1}\right)$.

d 1, 1, 3, 3,-tetramethylguanidine (TMG) and 1, 5-diazabicyclol4.3.0.]non-5-ene (DBN).

They are also higher than those of other secondary amides, such as $\mathrm{CH}_{3} \mathrm{CONHCH}_{3} \quad(\mathrm{PA}=212.7$ $\mathrm{kcal} / \mathrm{mol})$. These studies suggest that multiple bonding may stabilize the protonated peptide, and increase the proton affinities of peptides. Therefore, we might expect some increase in the proton affinity of peptides as the number of residue increases. Experimentally (Table 1) we found that the proton affinity of polyglycines increases steadily as the number of residues increases from one to ten.

The proton affinities jump $7.5 \mathrm{kcal} / \mathrm{mol}$ from glycine to diglycine. The jump can be explained by the multi- ple functional group interactions involved in the protonated diglycine and absent in the protonated glycine $[7,20]$. The proton affinity increases on average by about $4 \mathrm{kcal} / \mathrm{mol}$ with each additional residue from diglycine to pentaglycine. Between pentaglycine and decaglycine the proton affinity increases, but more slowly.

Increased proton affinity has been reported in other polymers, such as polyethers [22], and intramolecular hydrogen bonding has been suggested to play an important role. In addition to intramolecular hydrogen bonding, the increase through the series can also be 


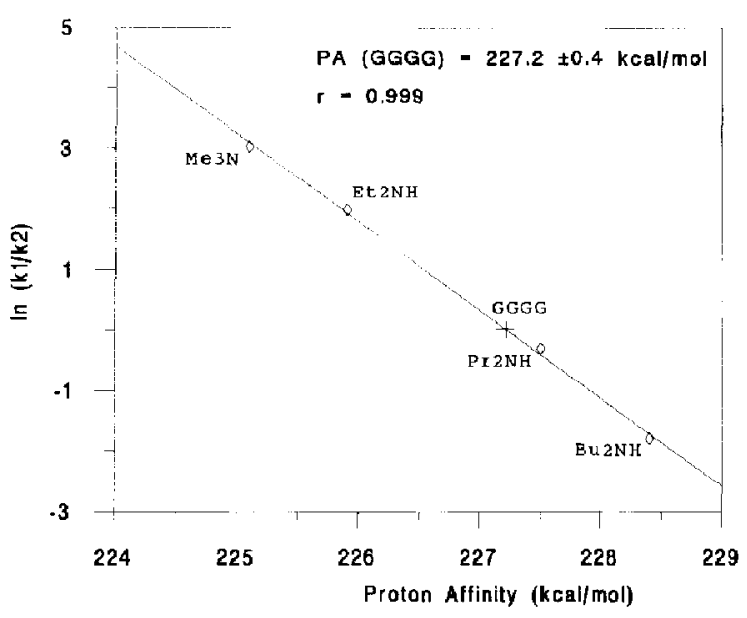

Figure 1. $\ln \left(k_{\text {(tetraglycine) }} / k_{\text {(amine)i }}\right.$ versus $\mathrm{PA}_{\text {(amine) } i}$. Calibration line for tetraglycine.

explained by charge-induced dipole interactions, or a simple statistical effect. For big peptides, the phenomena may also be attributed to the internal solvation of the proton.

\section{Acknowledgments}

This work was supported by a grant from the National Science Foundation (DIR-9013981). Mass spectral measurements were performed at the Structural Biochemistry Center at the University of Maryland Baltimore County. The authors thank Dr. R. J. Cotter and Dr. X Cheng for helpful discussions.

\section{References}

1. Biemann, K. In Methods in Enzymology, Vol. 193; McCloskey, J. A., Ed.; Academic I'ress: San Diego, California, 1990; p. 351.
2. Fenselau, C. In Annu. Rev. Bioptrys. Biophys. Chem., Vol. 20; Engelman, D. M., Ed.; Annual Reviews INC.: Palo Alto, California, 1990; p. 205.

3. Schwartz, B. L.; Bursey, M. M. Biol. Mass Spectrom. 1991, 21, 92.

4. Yeh, R. E.; Grimley, J. M.; Bursey, M. M. Riol. Mass Spectmm. $1992,20,443$.

5. Sakairi, M.; Yergey, A. L.; Siu, K. W. M.; Yvec Le Mlanc, J. C.; Guevremont R.; Berman, S. S. Anal. Chem. 1991, 63, 1488.

6. Meot-Ner(Mautner), M.; Hunter, E. P.; Field, F. H. J. Am. Chem. Soc. 1979, 101, 686.

7. Locke, M.; McIver, R. T. Jr. J. Am. Chem. Soc. 1983, 105, 4226.

8. Bujesen, G. J. J. Am. Chem Sic. 1987, 109, 5557.

9. Breindahl T.; Bojesen, G. Procetdings of the 12th International Mass Spectrometry Conference Amsterdam; 1991; WeA-B47.

10. Isa, K; Omote, T; Amaya, M. Organic Mass Spectrom. 1990, 25,620 .

11. Gorman, G. S.; Speir, J. P.; Turner, C. A.; Amster, I. J. J. Am. Chem. Soc. 1992, 114, 3986.

12. Wu, Z; Fenselau, C. Rapid Commun. Mass Spectrom. 1992, 6, 403.

13. Mclukey, S. A.; Cameron, D, Cooks, R. G. I. Am. Chem. Soc. 1981, 103, 1313.

14. Nourse, B. D.; Cooks, R. G. Int. J. Mass Spectrom. Ion Proc. $1991,106,249$.

15. Green, F; I.iguari, A.; Sindona, G. Uccella, N. J. Am. Chem. Soc. 1991, 122, 9092.

16. Burinsky, D.; Fukuda, E. Kr; Campana, J. E. J. Am. Chem. Soc. $1984,106,2770$.

17. Majumdar, T. K.; Clairet, F.; Tabet, J.-C.; Cook, R. G. J. Am. Chem. Soc. 1992, 114, 2897.

18. Boand, G.; Houriet, R.; Gaumann, T. I. Am. Chem. Soc. 1983, 105,2203 .

19. Lias, S. G.; Liebman J. F.; Levin, R. D. J. Phys. Chem. Ref. Date 1984, 13, 695.

20. Ment-Ner(Maitner), M. /. Am. Chem. Sor 1984, 106, 278

21. Raczynska, E. G.; Maria, P.-C.; Cal, J.-F.; Decouzon, M. Proceedings of the 12th International Mass Spectrometry Conference. Arnsterdam; 1991; MoA-A26.

22. Meot-Ner(Mautner), M. J. Am. Chem. Soc. 1983, 105, 4906. 